Journal of Business \& Management (COES\&RJ-JBM)

ISSN (E): 2306-7179 ISSN (P): 2306-8043

Publisher: Centre of Excellence for Scientific \& Research Journalism, COES\&RJ LLC

Online Publication Date \& Issue: $1^{\text {st }}$ January 2016, Vol.4, No.1, January 2016

http://centreofexcellence.net/J/JBM/JBM\&20Mainpage.htm

\title{
The administered public recreation marketing concept
}

\author{
Edouard V. Novatorov \\ Department of management \\ National Research University \\ Higher School of Economics \\ Russia \\ enovatorov@hse.ru
}

\begin{abstract}
:
The article focuses on four major assumptions that underlie the alternative conceptualization of public recreation marketing. It explains (1) the redistribution system within recreation resources are allocated; (2) the organizational structure of recreation agencies; (3) the ways in which public recreation agencies interact with local governments and citizens; and (4) the code of ethics and its influence on the behavior of recreation professionals. Finally, the article attempts to integrate these assumptions into an alternative definition of public recreation marketing that is termed "administered marketing."
\end{abstract}

Key words:

administered marketing, redistribution, code of ethics

\section{Citation:}

Novatorov , Edouard V. (2016; The administered public recreation marketing concept; Journal of Business \& Management (COES\&RJ-JBM) Vol.4, No.1, pp.47-59. 


\section{Introduction}

The past four decades have witnessed a worldwide acceleration in policies to privatize support for the provision of recreation services. While in some countries, such as the United States, this process started in the early 1970s, in other countries, such as Eastern Europe and the former Soviet Union, it is a relatively new trend stemming from the shift of these countries towards a free market system. In spite of differences in geography, political philosophy and commencement dates, the process of privatization in the recreation field is characterized by at least four general trends.

First, it appears that governments across the world have tended to reduce their responsibility and financial support for public recreation, emphasizing greater reliance on alternative financial sources such as, for example, user fees. Second, nonprofit and commercial institutions have been encouraged to enter the recreation field, to supplement or supplant public sector efforts. Third, public recreation agencies have entered into a variety of types of partnership with organizations from the nonprofit and commercial sectors. Fourth, academics through their journals and training programs have introduced business methods, techniques and tools to the public sector where environmental changes made managers receptive to such efforts.

Indeed, public administration scholars have actively sought to develop new, or borrow and adapt existing, private sector tools and concepts. Thus, public recreation administrators have sought to understand, and have attempted to transfer, commercial marketing tools and concepts to the fundamentally different operational environment of the public sector (Crompton and Lamb, 1986; Howard and Crompron, 1980; Leadly, 1992; O'Connell, et al., 2015, O’Sullivan, 1991, Rossman and Schlatter, 2015).

\section{Evolution of the Problem}

Although the concept of marketing in the nonprofit and public sectors was initially criticized in the marketing literature as confusing (Luck, 1969; 1974), it eventually became widely embraced by marketing scholars and consultants (Nickels, 1974). Lovelock and Weinberg (1978) noted that by the end of the 1970s there was no longer any serious controversy among marketing scholars about the appropriateness of the concept for the public and nonprofit sectors. However, despite this apparent agreement among marketing academics, public administrators and academics in public administration areas, including recreation field, have not unanimously embraced the utility of the concept of public sector marketing. Hunt (1976) stated the problem:

Thus, the major substantive problem concerning broadening the concept of marketing lies in the area of marketing to nonmarketers. (italics original) (p. 24).

During the subsequent two decades the "marketing to nonmarketers" problem in the context of the public sector, has split public administrators into two camps comprised of its supporters and opponents. Thus, Roberto (1991, p. 81), an active proponent of marketing, observed: "Marketing's recent and growing participation in public sector management has received a bipolar love-hate evaluation." The opponents' position was perhaps best articulated by Walsh (1994, p. 68) who suggested the need to redefine public marketing "...if it is to be specifically public service marketing rather a pale imitation of a private sector approach within the public sector." Thus, the emergence of controversial debate on the "marketing to nonmarketers" issues in recreation field was not unexpected (Havitz, 1988; Schultz, et.al, 1988). 


\section{The Emergence of Marketing in Public Recreation Agencies}

Interest in the application of marketing principles within the public recreation field also emerged at the end of the 1970s. This interest was stimulated by two major trends in public recreation. First, professionals in many countries were looking for innovative management tools to increase the efficiency and effectiveness of recreational program delivery. Second, traditional ways of financing public leisure programs changed in both Western European and in North American countries (Crompton and McGregor, 1994, O'Sullivan, 1991).

The "tax revolt" in the late 1970s and early 1980s, which was manifested by such laws as California's Proposition 13 and Missouri's Hancock Amendment, resulted in dramatic decreases in budgeted tax support for recreational services and simultaneous pressures to increase revenues from sources other than tax funds. As a result of these environmental changes, a metamorphosis of recreation managers took place as they had to become more entrepreneurial; look for nontraditional means of financing and operating public recreation facilities; be more concerned with efficiency and effectiveness; employ innovative management strategies; and accept a new philosophy of doing "more with less" in the provision of recreation services (Crompton, 1987).

\section{Conceptualization of Public Recreation Marketing}

Crompton (1983a, p. 7) defined recreation marketing as: "a set of activities aimed at facilitating and expediting exchanges with target markets." This definition was adopted by the National Park Service (Marketing Parks and Recreation 1983, p. 3), while O'Sullivan (1981, p. 1) preferred to borrow Kotler's (1975a) broader definition of marketing as "human activity directed towards satisfying needs and wants through exchange processes." Perhaps, the most comprehensive definition of marketing, because it included marketing management aspects, was suggested by Howard and Crompton (1980, p. 320) who largely drew much of their framework from Kotler's (1975a) conceptualization of nonprofit marketing:

Marketing is the analysis, planning, implementation, and control of carefully formulated programs designed to bring about voluntary exchanges with target markets for the purpose of achieving agency objectives. It relies heavily upon designing offerings consistent with clients' wants, and on using effective pricing, communication and distribution to inform, motivate, and service the markets.

This conceptualization of recreation marketing rests on several fundamental concepts: (1) the organization as a resource converting mechanism, (2) voluntary exchange, (3) the notion of publics, (4) the marketing mix, (5) the marketing environment, and (6) equity. It postulates that a recreation agency operates in an environment with an array of different categories of publics. A public is defined as "a distinct group of people and/or organizations that have an actual or a potential interest in, or impact upon, the recreation and park agency" (Howard and Crompton 1980, p. 321). In order to survive, the recreation agency must first attract resources, in the form of money to acquire land, labor, and materials from one category of publics; second, convert the attracted resources into programs, services, and facilities using internal publics and/or related government publics; and, third, distribute the converted resources through allocation decisions to various consuming publics.

In these definitions, voluntary exchange is presented as the only plausible conceptual option available to the recreation agency for attracting, converting and distributing resources. Thus, exchange is considered to be the central concept underlying recreation marketing. At a minimum, exchange requires the existence of two simple conditions. First, there should be two or more parties. Second, each party must possess something that is valued by the other party. Thus, a park and recreation agency seeks to obtain resources and support from citizens 
in the form of tax dollars and user charges, in exchange for the recreation services and benefits that it delivers.

The set of marketing activities includes market intelligence, targeting market segments, establishing objectives, and developing strategies for effective service delivery by using the elements of the marketing mix. The marketing mix embraces four activities: developing programs, pricing them, scheduling and locating them, and promoting them. The components of the marketing mix have been popularly represented as the "4 Ps" (product, price, promotion, and place). In contrast to noncontrollable factors that characterize the marketing environment, these four elements are considered to be the set of factors controllable by a recreation agency. This application comprises the management aspect of the marketing definition. An agency should carefully analyze the opportunities and constraints in its external environment and use the four marketing mix elements to develop strategies that will lead to achievement of organizational goals. (O'Connell, et al., 2015).

\section{Limitations of the Conceptualizations}

Recreation professionals have not challenged the appropriateness of applying marketing tools to the delivery of public recreation services. However, some have challenged its conceptual underpinning. They have expressed concern about the marketing philosophy being an appropriate model for recreation management, and about voluntary exchange being a legitimate framework capable of incorporating equity considerations.

Godale (1985) argued that all responses to financial constraints could be classified into two types: strategies for reducing costs (e.g. increasing use of volunteers, computerization, privatization and public-private contracting, voucher systems) and strategies for increasing financial resources (e.g. establishing user fees and charges, application of marketing techniques and orientation). Godale (1985) maintained that while strategies for reducing costs are not necessarily inconsistent with the mission and tasks of public recreation agencies, strategies for increasing financial resources, including a marketing orientation, have more potential for being inconsistent with the objectives and mandate of public recreation services. He believed that concern with increasing financial resources in a public recreation agency tends to shift the focus of managerial attention towards immediate financial considerations at the expense of social objectives.

Opponents of marketing argue that application of the marketing philosophy to increase revenues and improve efficiency distorts public recreation agency objectives, contradicts the social service ethic, and invites commercialization of the public recreation field (Dustin and Godale, 1997; Godbey, 1991; Schultz, et al., 1988). For example, Schultz et al. (1988, p. 54) believe that the philosophy of marketing is to convince people that "their desires are real needs and they must have what is for sale." Godbey (1991, p. 56) contends that "marketing public services differs from similar efforts in the commercial sector in a fundamental waythe public sector must market for more than economic profit." Although Havitz (1988) put forward counter arguments emphasizing the inherent neutrality of the marketing philosophy and marketing techniques for both sectors, and that the marketing philosophy and social service ethic are entirely compatible, the issue remains controversial.

\section{Development of an alternative conceptualization}

The Redistribution System of Recreation Resources

Von Mises (1944, p. 84) once ironically observed: "The truth is that the government cannot give if it does not take from somebody." For generations, property and sales taxes levied on citizens have been the primary sources of both operational and capital funds for public recreation agencies. The annual collection of taxes and the expenditures of some of 
them on recreation services confirm that the recreation field is part of the public sector, which also has been referred to as the bureaucratic or redistributive sector (Dalton, 1971).

Dalton (1971, p. 93) noted that in any society "where there is a centralized political authority, there is a redistributive sector." It appears that the reverse relationship is also true. Any redistributive effort requires a centralized and socially recognized political authority that operates on the basis of commonly accepted rules or laws for implementing redistributive actions. Dalton (1971) defines redistribution as the obligatory payment of material items or money to a central political authority which uses the receipts for its own maintenance, to provide community services, and as an emergency reserve in case there is a community disaster. Thus, in the context of public recreation, redistribution can be defined as the obligatory payment of property and sales taxes to local and state governments, and income taxes to state and federal governments, which reallocate portions of what they receive to provide recreational services for the community. This definition is consistent with the premises advocated by Galbright (1956) and Hardin (1968), who believed that government is the people and it is the people who democratically accept and mutually agree upon the use of coercion to collect taxes and use them for recreational services.

Redistribution is one of the several ways in which recreational needs can be satisfied. They can also be satisfied through private household arrangements, free market exchange, and reciprocity relationship mechanisms. Commercial theme parks such as Disney World, donations from charitable organizations for recreational services which played a major role in launching the public recreation movement at the beginning of the twentieth century, and weekend games in one's own home backyard, are simple examples of market exchange, reciprocity and households arrangements respectively.

The prominent role of the redistribution system stems from a premise that recreation is a public good. For example, a declaration developed by the North American leaders of the recreation movement stated: "increased leisure is a public good, one of the benefits of progress, and a measure of our nations' wealth and well-being." According to the declaration, "more leisure time and better distribution of work and income can assist in solving economic and social problems." These premises commit recreation leaders to strategies for action that ensure that "recreation opportunities are available for all North Americans." (North American Declaration, 1995).

The lack of accessibility of some segments to market provided recreation services, the lack of backyards for some Americans, and the selective and non-permanent peripatetic nature of donations and gifts, make redistribution the preferred organizational and control system for providing recreational resources and ensuring access to most community members. For example, Dustin, et al. (1995), extrapolating from Hardin (1968), suggest that sole reliance on market forces would eventually affect recreation services in a negative way. Similarly, Brody (1985) points out the impulsive nature of reciprocal grant and gift giving.

In contrast to the market exchange and reciprocity socio-economic arrangements that function as between relations between two or more parties, a redistribution system reflects a within and collective action of a group (Sahlins, 1965). It constitutes a hierarchically structured group, with a commonly recognized leadership and a clearly defined membership, which pools resources, and has agreed distributive rules. The size of the group can vary. It can be a family, group of friends, local community, interest group, or state. Irrespective of the size of the group, the redistribution system stipulates the unity and centralized organization of the group. 
The commonly recognized center or leadership refers to the city council or other elected legislative body, and/or the city manager or other form of government chief executive officer. As well as preferring the right to vote for political and administrative leadership, membership of the group is defined by rules. These rules can be family or kinship ties; citizenship with a state; or residency with a community.

The pooling of resources refers to the payment of taxes in accordance with prevailing laws. Finally, the distributive rule refers to the community's definition of redistributive justice and the criterion of equity adopted. At all levels of government, the general form of the redistribution system is the same: (1) taxes or resources are pooled into a general fund by a dominant political center; (2) the political center takes allocation decisions and subsidizes the provision of recreation services. Once resources have been collected into a jurisdiction's general fund, the central authority is confronted with the primary question of redistribution that is: "who gets what, when, and how." "Who" refers to the segments of the large community. Usually they are defined by either demographic characteristics such as age and ethnicity, or by economic factors such as an income. "What" refers to the types of services or goods to be subsidized from the general fund. "When" refers to the planning process. Among other elements it includes the establishment of goals and deadlines; accepting and approving proposals; the planning of budgets and programs; and the scheduling of an audit process. Finally, "how" refers to the actual processes of service delivery, that is the marketing and management of services. It includes routine decision-making; personnel issues; efficiency and effectiveness considerations; user fee structures; and the like.

\section{The Public Recreation Organization}

In contrast to profit oriented recreation organizations that tend to be open-ended systems with wide discretion, public recreation agencies tend to be closed-ended systems with a relatively narrowly defined mission. Both private and public recreation agencies render useful services to the community. However, evidence of the usefulness of these services for the community is determined differently. In the case of private profit-seeking organizations, usefulness of their services is determined by citizens' willingness to pay the price asked for them. If they are willing to pay, then production of such services grows until saturation of the market is reached, at which point the factors of production will shift toward other services that are in greater demand. The profit motive and price structure of the market serve as a sensitive compass to organizations indicating the right amount of services to produce, and the right services in which to invest money. Under these circumstances management of profit seeking organizations tends to be flexible, discrete, and de-centralized because anything that may slow down the organization's ability to adapt to changing customer preferences may be fatal to the continued viability of the organization. It is not management that lays off employees and dissolves profit-seeking organizations, it is the disapproval of the organization's customers that results in an excess of costs over revenues that leads to such actions.

In the case of public recreation agencies, the mechanics of viability are quite different. An agency is not primarily concerned with citizens' willingness to pay or with an excess of revenues over costs. Public managers are concerned with being responsible stewards of taxpayers' money. They are allocated a fixed amount in the form of a budget. An agency tends to be centralized and closed-ended, and its managers typically are given only relatively narrow discretion because of the overriding concern that the agency be accountable for spending taxpayers resources in accordance with the directions of elected representatives (Rossman and Schlatter, 2015).

Although the rules and regulations governing the provision of recreation services vary between municipalities, it is possible to identify some general characteristics of public organizations that operate with relatively wide discretion, but within a relatively narrow 
defined mission. In such cases, it is important to distinguish a "core area of mission" related to the central doctrine underlying activities of a public agency, and "an extant mission" related to the entrepreneurial activities of public agencies (Capon and Mauser, 1982). A core area of mission is usually associated with those services that are financed directly and fully from the general fund. An extant mission relates to such activities as self-efficient programs and services partially paid for directly by citizens. A core area of mission, e.g. to provide recreational services to a community, is unlikely to change without significant political changes. However, the extant mission can change as many times as an agency's management believe is necessary to better serve the recreation needs of the community, provided that city council approves it.

The strong control typically exercised by a city council over the core area of mission and the spending of general fund resources designated for community parks and recreation suggests that departments of recreation tend to be closed-system organizations with a clearly specified goal and relatively little dependence of the external environment.

\section{The Interaction with its Environment}

Many conceptualizations of public sector or nonprofit marketing tend to be based on the exchange concept that invites an economic type of analysis. From a redistribution system perspective, the exchange interpretation of public sector marketing is inadequate. First, it shows only a small proportion of the full set of relationships that exist between government and citizens, by focusing only on the direct organization-service beneficiary relationships. According to this perspective, the agency is the center of the universe and government is a sputnik rotated around the agency. This is the microeconomic system type of analysis where marketing refers to agency A inducing behavior in interest group B, not for B's benefit, but for A's since success of A's marketing efforts is measured by profit earned by A (Dixon, 1978). Because the organization is the primary unit of such an analysis the administrative role of government is minimized and limited, so the public parks and recreation agency is incorrectly perceived to be the initiator of all marketing efforts and government is incorrectly perceived as an implicit constraint to such efforts.

Dixon (1978) argues that the application of microeconomic analysis to the activities of public agencies creates confusion. The public recreation agency, which is a subsystem of the larger redistribution system, is perceived to absorb this redistribution system so the agency becomes the dominant system and government a subsystem. The redistribution system implies that a public agency is a subsystem of the redistribution system. A redistribution perspective analyses interaction between government, public agency, and citizens as a top-bottom hierarchical relationship, where the government is the center of the universe, and the public agency, as well as non-profit and profit organizations, are sputniks rotated around it.

From the within relation perspective, which is characteristic of the redistribution system, it is important to understand these relationships as top-bottom organized and involving two relatively independent steps. The first step is the collection of taxes from bottom to the top, and the second step is the delivery of services from top to bottom. If these premises are accepted, then the quid pro quo notion of dyadic exchange and rules of generalized reciprocity are logically replaced with the concept of redistributive justice and forms of equity. The role of government as central political authority becomes dominant and the public agency assumes an appropriate place and role within the larger redistribution system (Figure $1)$.

\section{The Motivation of Park and Recreation Professionals}

Employees join a public recreation agency because they believe it is in their self-interest. Government is perceived as an employer who hires labor as a factor of production to deliver 
services to the community. However, this appears to be the only similarity between the motivations of personnel in private profit-seeking organizations and those in public agencies. There are arguments that suggest that a public recreation agency should be driven by concerns for the public interest rather than by employees' self-interest. In the private firm individuals combine for the primary aim of making a profit. Von Mises (1944, p. 64) noted that: "under the profit motive every industrial aggregate, no matter how big it may be, is in a position to organize its whole business and each part of it in such a way that the spirit of capitalist acquisitiveness permeates it from top to bottom." The interpretation of self-interest motivation as giving license to an unlimited spirit of acquisitiveness has been criticized as being immoral, egotistic, and selfish.

Implementation of the will of the majority by the state implies the use of benevolence and malevolence motivational methods such as fear and love (Boulding, 1973). Collection of taxes under a redistribution system to finance the provision of recreation and park services reflects the will of the majority. Those who agree to pay taxes expect government to deliver quality recreation services. Those who disagree with it are forced to pay taxes anyway or be prepared to accept legal actions for not paying taxes.

The American Society for Public Administration's (ASPA) Code of Ethics was developed as a set of moral principles in 1981 by the Society for Public Administration's National Council. Three years later in 1984, the Council approved a Code of Ethics for ASPA members. In 1994 the Code was revisited. The revisited code consists of five topics and 32 articles. The first topic "Serve the public interest" encourages public servants to "serve the public, beyond serving oneself."

If the community of recreation professionals recognize themselves as public administrators then the ASPA's code of ethics can serve as useful guidelines in their management and marketing decisions. Capon and Mauser (1982) and Laszniak et al. (1979) point out that in the general marketing literature, ethical issues in the context of nonprofit marketing remain "surprisingly silent."

Figure 1: Administered Marketing
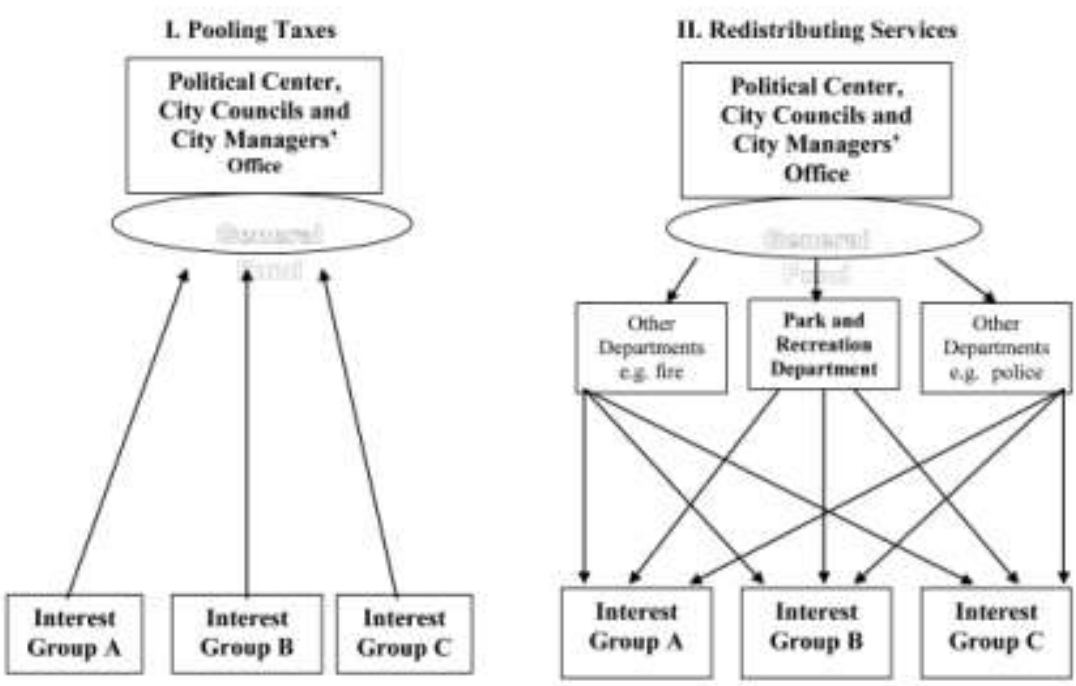


\section{The Concept of Administered Marketing}

The historical root of administered marketing is administered trade. Under administered trade "prices, as well as all other terms, had been negotiated with the king before any transactions could take place" (Arnold, 1957, p. 168). Historical records document that under the system of administered trade the king "fixes the price of every sort." After "the terms were agreed upon and the king's customs paid" the merchant had "full liberty to trade, which is proclaimed throughout the country by the king's cryer" (Arnold, 1957, p. 168). Although records of administered trade stem from the eighteenth century, they seem to aptly describe the modern regulation policies of local government regarding collection of taxes and the approval of fee structures for some government services including parks and recreation.

Redistribution is the central concept underlying administrative marketing. A city council, as an elected and commonly recognized political authority collects property and sale taxes from citizens and deposits them into the general fund. After taxes have been collected, they are distributed among the different services delivered to the community. Government establishes the department of parks and recreation, finances it, determines its goals, mission, and rules, and authorizes it to provide services for the community including some that require fees. A department of parks and recreation is a bureaucratic closed-system agency with a clearly defined mission, moral principles, hierarchical structure, and internal arrangements designed to effectively implement the mission.

A professional administrative marketer is someone who seeks to understand, plan, and manage redistributive arrangements. She or he would not be expected to focus upon selling the agency's services and generating revenue, but to look at the agency, its mission, and its problems in a rational manner: identifying objectives; discovering the recreational needs of citizens through research; weighing the opportunities and constraints; determining the resources available to the agency and exploring alternative sources of resources; examining the various ways, in which client requirements can be met and the amount of human resources and type work that needs to be done.

Additionally, an administrative marketer would be concerned with the resources, efforts, and time that citizens, donors, and partners are willing to contribute; location of the agency's facilities and scheduling of times when these services are offered; behavior of employees in accordance with established moral standards and, finally, control mechanisms which help to determine if the agency is functioning as planned, or whether changes and adjustments are required in response to new citizen demands. All of this is embraced in the following definition of administered marketing:

\section{Administered marketing is the analysis, planning, implementation, and control of programs designed to facilitate redistributive arrangements within a community for the purpose of achieving established community objectives.}

\section{Conclusion}

The concept of administered marketing differs from existing conceptualizations in several important ways. Conceptualizations of nonprofit marketing can be characterized as a continua. On one side would be located perspectives that consider marketing as a set of tools for managing exchanges (e.g. Coffman, 1986; Crompton and Lamb, 1986b; Mokwa et al., 1980; Kotler, 1975; Lovelock and Weinberg, 1984; Manoff, 1985; McCort, 1994; Rossman and Schlatter, 2015). Marketing is perceived as being concerned with satisfying clientele needs and, hence, the marketing is defined as identifying and fulfilling visitors needs through the integrated use of marketing tools with the goal of creating consumer satisfaction, which is the organization's primary goal (Kotler, 1975). This is most dominant perspective underlying 
most conceptualizations developed for recreation field (Howard and Crompton, 1980; Leadly, 1992; O’Connell et al., 2015; O’Sullivan, 1991; Torkildsen, 1991).

At the other end of the continuum are perspectives that do not consider marketing to be defined by with exchange processes. These perspectives discard both the voluntary exchange of values and marketing concept as means for meeting visitors' needs. According to these conceptualizations, marketing is a set of tools designed to induce behavior change. From this premise, the marketing concept is defined as inducing changes in existing patterns of behavior. Persuasive communications and adapting to existing patterns of behavior are seen as marketing's two primary characteristics. This perspective distinguishes between a core area of mission and an augmented mission and argues that tools of persuasion are central to achieving the core area of mission, while marketing and sales orientations are appropriate for the augmented mission activities (Capon and Mauser, 1982; Lauffer, 1984; Rados, 1981).

Between the continuum extremes, there are conceptualizations that incorporate elements of both extremes. For example, Dixon (1978) does not accept the conceptualization of marketing as a management technology, arguing that marketing is a social activity and a social science concerned with study of such market activities as buying and selling. A similar conceptualization but with different nuances is offered by Pandya and Dholakia (1992) who positioned their approach in the political economy paradigm developed in the marketing literature by Arndt (1981). Their perspective advocates conceptualization of social marketing based on both exchange and redistribution and reciprocity arrangements.

Administered marketing is a synergetic concept. It accepts the premise of supporters of exchange conceptualizations that marketing is a management technology. However, it rejects the concept of voluntary exchange as being universal and as underlying all of marketing activities. Instead, it recognizes the concept of redistribution, but does not accept that it is merely another form of exchange. Economic anthropologists, historians and public scholars derive it from the classic notion of redistribution with all the rules and premises that comprise this system.

\section{Literature}

Arndt, J. (1981, Fall). The political economy of marketing systems: Reviving the institutional approach. Journal of Macromarketing, 1(2): 36-47.

Arnold, R. (1957) A port of trade: Whydah on the guinea coast. In Polanyi, K., Arensberg, C. M., and Pearson, H. W. (Eds.) Trade and market in early empires (pp. 145-174). New York: The Free Press.

Boulding, K. (1973). The economy of love and fear. Belmont, CA: Wadsworth.

Brody, J. G. (1985, October). Informal social networks: Possibilities and limitations for their usefulness in social policy. Journal of Community Psychology, 13(4): 338-349.

Capon, N. and Mauser, G. (1982, Summer). A review of nonprofit marketing texts. Journal of Marketing, 46, (3): 125-128.

Coffman, L. (1986). Public sector marketing: A guide for practitioners. New York: John Wiley and Sons.

Crompton, J. L. (1983). Selecting target markets--A key to effective marketing. Journal of Park and Recreation Administration, 1(1): 7-26. 
Crompton, J. L. (1987). Doing more with less in parks and recreation services: A book of case studies. State College, PA: Venture Publishing.

Crompton, J. L. and Lamb, C. H. (1986). Marketing government and social services. New York: John Wiley and Sons.

Crompton, J. L. and McGregor, B. P. (1994). Trends in the financing and staffing of local government park and recreation services 1964/65-1990/91. Journal of Park and Recreation Administration, 12(3): 19-37.

Dalton, G. (1971). Primitive, archaic, and modern economies. In G. Dalton (Ed.) Economic anthropology and development. New York: Basic Books.

Dixon, D. (1978, Summer). The poverty of social marketing. MSU Business Topics, 26: 5056.

Dustin, D. and Godale, T. (1997, July). The social cost of individual "benefits." Parks and Recreation. 31: 20-21.

Dustin, D. L., McAwoy, L. H., and Schultz, J. H. (1995). Stewards of access/custodian of choice: A philosophical foundation for the park and recreation profession. (2d ed.)

Champaign, IL: Sagamore Publishing.

Galbright, J. K. (1956). American capitalism. Boston, Mass: Houghton Mifflin. Hardin, G. (1968, December 8). The tragedy of commons. Science: 1245-1248.

Godale, T. (1985). The political economics of local leisure services. Journal of Park and Recreation Administration, 3(1): 14-27.

Godbey, G. (1991, October). Redefining public parks and recreation. Parks and Recreation, 56(10): 56-61.

Havitz, M. E. (1988, May). Marketing is not synonymous with commercialism. Parks and Recreation, 23(5): 34-36.

Howard, D. and Crompton, J. (1980). Financing, managing, and marketing recreation and park resources. Dubuque, Iowa: Wm. C. Brown Company.

Hunt, S. D. (1976, July). The nature and scope of marketing. Journal of Marketing, 40(3): 1728.

Kotler, P. (1975). Marketing for nonprofit organizations. Englewood Cliffs, NJ: Prentice Hall.

Laszniak, G. R., Lusch, R. F. and P. E. Murphy (1979, Spring). Social marketing: its ethical dimensions. Journal of Marketing, 43(2): 29-36.

Lauffer, A. (1984). Strategic marketing for not-for-profit organizations. New York: The Free Press.

Leadley, P. (1992). Leisure marketing. Harlow, Longman/ILAM Leisure Management Series. 
Lovelock, C. H., and Weinberg, C. B. (1978). Public and nonprofit marketing comes of age. In G. Zaltman and T. Bonoma (Eds.), Review of Marketing 1978 (pp. 413-452). Chicago, IL: American Marketing Association.

Lovelock, C. H., and Weinberg, C. B. (1984). Marketing for public and nonprofit managers. New York: John Wiley.

Luck, D. (1969, July). Broadening the concept of marketing--Too Far. Journal of Marketing, 33(3): 53-55.

Luck, D. (1974, October). Social marketing: Confusion compounded. Journal of Marketing, 38(4): 70-72.

Manoff, R. K. (1985). Social marketing: New imperative for public health. New York: Praeger Publishers.

McCort, D. J. (1994, Spring). A framework for evaluating the relational extent of a relationship marketing strategy: The case of nonprofit organizations. Journal of Direct Marketing, 8(2), 53-59.

Mokwa, M. P., Dawson, W. M. and E. A. Prieve (1980). Marketing the arts. New York: Praeger Publishers.

Nickels, W. G. (1974, Winter). Conceptual conflicts in marketing, Journal of Economics and Business, 27(1): 140-3.

North American Declaration (1995, August 15). Initial draft by delegates to the North American Executive Institute, Ottawa, Canada.

O'Connell, T, Cuthbertson, B, Goins, T. (2015). Leadership in Recreation and Leisure Services. Human Kinetics.

O’Sullivan, E. L. (1991). Marketing for parks, recreation and leisure. State College, PA: Venture Publishing.

Pandya, A. and Dholakia, N. (1992). An institutional theory of exchange in marketing, European Journal of Marketing, 26(12): 19-41.

Rados, D. L. (1981). Marketing for nonprofit organizations. Boston, MA: Auburn House.

Roberto, E. (1991). Applying a marketing model in the public sector. In O'Fairchellaigh, C., Graham, P., and Warburton, J. (1991), Service delivery and public sector marketing (pp. 112134). Sydney: Macmillan \& Co.

Rossman, J. R. and Schlatter, B. E. (2015). Recreation Programming, 7th ed. Sagamore Publishing.

Sahlins, M. D. (1965). On the sociology of primitive exchange. In M. Banton (Ed.) The relevance of models for social anthropology (pp. 139-236). London: Tavistock Publications.

Schultz, J. H., McAvoy, L. H. and Dustin, D. L. (1988, January). What are we in business for? Parks and Recreation, 23(1): 52-54. 
Journal of Business \& Management (COES\&RJ-JBM), 4(1), pp. 47-59

Torkildsen, G. (1991). Leisure and recreation management, (3d. ed.), London: E. and F. N. Spon.

Von Mises. L. (1944) Bureaucracy. New Haven: Yale University Press.

Walsh, K. (1994). Marketing and public sector management. European Journal of Marketing, 28(3): 63-71.

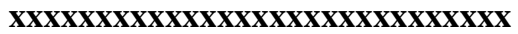

